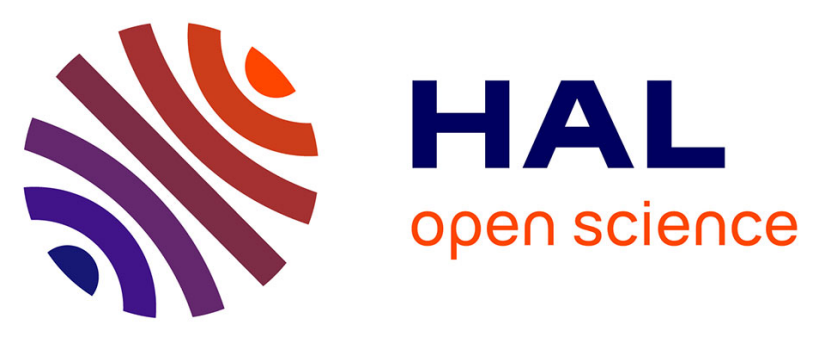

\title{
Poster Abstract: Performance Evaluation of Machine-to-Machine Communication on Future Mobile Networks in Disaster Scenarios
}

\author{
Thomas Pötsch, Safdar Khan Marwat, Yasir Zaki, Carmelita Görg
}

\section{- To cite this version:}

Thomas Pötsch, Safdar Khan Marwat, Yasir Zaki, Carmelita Görg. Poster Abstract: Performance Evaluation of Machine-to-Machine Communication on Future Mobile Networks in Disaster Scenarios. 19th Open European Summer School (EUNICE), Aug 2013, Chemnitz, Germany. pp.270-273, 10.1007/978-3-642-40552-5_24. hal-01497050

\section{HAL Id: hal-01497050 \\ https://inria.hal.science/hal-01497050}

Submitted on 28 Mar 2017

HAL is a multi-disciplinary open access archive for the deposit and dissemination of scientific research documents, whether they are published or not. The documents may come from teaching and research institutions in France or abroad, or from public or private research centers.
L'archive ouverte pluridisciplinaire HAL, est destinée au dépôt et à la diffusion de documents scientifiques de niveau recherche, publiés ou non, émanant des établissements d'enseignement et de recherche français ou étrangers, des laboratoires publics ou privés.

\section{(c)(1)}

Distributed under a Creative Commons Attribution| 4.0 International License 


\title{
Poster Abstract: Performance Evaluation of Machine-to-Machine Communication on Future Mobile Networks in Disaster Scenarios
}

\author{
Thomas Pötsch ${ }^{1}$, Safdar Nawaz Khan Marwat ${ }^{1}$, Yasir Zaki², and \\ Carmelita Görg ${ }^{1}$ \\ ${ }^{1}$ Communication Networks, TZI, University of Bremen, Germany \\ [thp $\mid$ safdar $\mid$ cg] @comnets . uni-bremen.de \\ ${ }^{2}$ Computer Science Department, New York University Abu Dhabi (NYUAD), \\ Abu Dhabi, United Arab Emirates \\ yz48@nyu.edu
}

Long Term Evolution (LTE) is the recent standard of wireless communication developed by the Third Generation Partnership Project (3GPP). As the future mobile network, it is currently being rolled out to numerous areas world-wide. Besides other objectives such as enhancing the spectral efficiency and reducing latency for broadband services, LTE has been designed as a pure packet switched system. Hence, it targets the data volume requirements of cellular mobile users by increasing the peak-user data throughput to up to $100 \mathrm{Mbit} / \mathrm{s}$ [1]. However, legacy circuit switched services are no longer supported by this technology. Contrary to the existing, wide-spread GSM network, this implies that the support of voice calls and Short Message Service (SMS) have to be realized by voice and SMS via the IP Multimedia Subsystem (IMS). In other words, voice calls are no longer separated from pure data traffic and hence influence each other.

Along with the "Internet of Things" as a new paradigm for connected devices, Machine-to-Machine (M2M) communication is a world-wide, fast growing field of application. According to [3], the mobile traffic of the variety and number of connected devices will grow significantly within the next decade. Therefore, the multitude of remotely monitored equipment is growing and includes buildings, vending machines, vehicles and other physical equipment. The application fields incorporate for example health monitoring, logistics and shipping, environmental monitoring, or asset tracking. Besides that, the overall mobile network is expected to grow 24-fold from 2012 to 2017 and the number of mobile connected devices will exceed the world's population by the end of 2013 [3].

Looking at the increasing number of mobile connected devices and on one particular scenario where mobile communication is very beneficial in terms of life-saving measures, the capacities of future mobile networks are becoming more and more important. Over the past decades, natural disaster and emergency events have been increasing significantly all over the world [4][2]. Although the capabilities of predicting natural disasters have been become more precise and reliable, certain natural disasters are unpredictable. Besides that, other emergency events such as terror attacks or multiple accidents are not predictable at all, and when occurring, mostly numerous people are affected. However, throughout almost any emergency event, mobile communication plays an important role 
for both, involved persons and rescue activities. Besides the regular and existing network traffic, additional traffic emerges and is indirectly caused by the emergency event itself. However, taking such a scenario as a rather rare and unlikely event, but where mobile communication plays a tremendous and important role, M2M operators have to cope with severe challenges, like for example, how does M2M communication perform in an emergency event when numerous people instantaneously begin to use IP-based services. Although a possible off-time of M2M communicating devices does not play a severe role, an off-time of devices facilitating e-healthcare, etc. might be critical.

Figure 1 shows an example of the traffic load in a mobile network during an event of disaster. Shortly after an event of disaster, the traffic load of the mobile network increases significantly by emergency calls. Right after emergency calls, people usually start sending out messages to notify others about their current situation and condition. Those messages could be regular phone calls, text messages and/or status updates in social networks. Nowadays, SMS services have been widely replaced by Instant Messaging (e.g. Whatsapp, iMessage, etc.) and social networking (e.g. Facebook, Google+, etc.) have been become very popular. Therefore, it is very likely that people start sending out numerous messages, pictures and videos to inform others about their current situation and to spread the scale of the disaster to others.

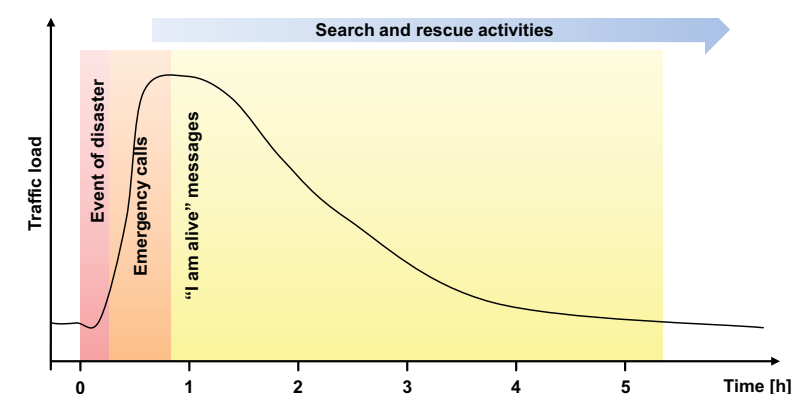

Fig. 1: Example of Traffic Load in Event of Disaster (adapted from [5])

To investigate the influence of such a situation, a simulation model was developed using the OPNET simulator [6] with the main focus on end-to-end performance evaluations on the user plane. All nodes in the network contain the full protocol stack implementation that was done following the $3 \mathrm{GPP}$ release 8 specification. Further details of the simulation model can be found in [7] and [8].

During the first 1000 seconds of the simulation, the scenario consists of 10 VoIP users, 10 file transfer users and 100 M2M devices. M2M devices and file transfer users share the same QoS class. These terminals are operating continuously with the parameters shown in Table 1. After 1000 seconds, an emergency event occurs where additionally 60 emergency VoIP users and 30 Instant Messaging (IM) users start to operate. The emergency VoIP users behave like regular VoIP users whereas the IM user start sending messages, videos and pictures. 


\begin{tabular}{|c|c|c|c|}
\hline Parameter & Setting & Parameter & Setting \\
\hline Cell layout & 1 eNodeB, 3 Cells & \multicolumn{2}{|c|}{ File transfer traffic model } \\
\hline System bandwidth & $5 \mathrm{MHz}(\sim 25 \mathrm{PRBs})$ & Quantity & 10 \\
\hline \multirow{2}{*}{$\begin{array}{l}\text { Frequency reuse } \\
\text { factor }\end{array}$} & \multirow[t]{2}{*}{1} & File size & $2 \mathrm{MB}$ \\
\hline & & \multirow{2}{*}{$\begin{array}{l}\text { File inter- } \\
\text { request time }\end{array}$} & \multirow{2}{*}{$\begin{array}{l}\text { Uniform } \\
(15 \mathrm{~s}, 25 \mathrm{~s})\end{array}$} \\
\hline Cell radius & $375 \mathrm{~m}$ & & \\
\hline UE velocity & $3 \mathrm{~km} / \mathrm{h}$ & \multicolumn{2}{|c|}{ M2M traffic model } \\
\hline Max UE power & $23 \mathrm{dBm}$ & Quantity & 100 \\
\hline \multirow[t]{2}{*}{ Path loss } & \multirow{2}{*}{$\begin{array}{c}128.1+37.6 \log _{10}(\mathrm{R}) \\
\mathrm{R} \text { in } \mathrm{km}\end{array}$} & Message size & $6 \mathrm{kB}$ \\
\hline & & \multirow{2}{*}{\begin{tabular}{|c|} 
Message inter- \\
transmission time
\end{tabular}} & \multirow[t]{2}{*}{$30 \mathrm{~s}$} \\
\hline \multirow[t]{3}{*}{ Slow fading } & \multirow{3}{*}{\begin{tabular}{|c|}
$\begin{array}{c}\text { Log-normal shadowing, } \\
8 \mathrm{~dB} \text { standard deviation, } \\
\text { correlation } 1\end{array}$ \\
\end{tabular}} & & \\
\hline & & \multicolumn{2}{|c|}{ Instant messaging traffic model } \\
\hline & & Quantity & 30 \\
\hline Fast fading & Jakes-like method & \multirow{2}{*}{ Message size } & \multirow{2}{*}{$\begin{array}{c}\text { Uniform } \\
(0.2 \mathrm{kB}, 2 \mathrm{MB})\end{array}$} \\
\hline Mobility model & Random Way Point & & \\
\hline UE buffer size & $\infty$ & \multirow{2}{*}{$\begin{array}{l}\text { Message inter- } \\
\text { request time }\end{array}$} & \multirow{2}{*}{$\begin{array}{l}\text { Uniform } \\
(10 \mathrm{~s}, 20 \mathrm{~s})\end{array}$} \\
\hline \multirow[t]{2}{*}{ Power control } & \multirow{2}{*}{$\begin{array}{c}\text { Fractional PC, } \alpha=0.6, \\
\mathrm{P}_{0}=-58 \mathrm{dBm}\end{array}$} & & \\
\hline & & \multicolumn{2}{|c|}{ Voice traffic model } \\
\hline Traffic environment & Loaded & Quantity & $10+60$ emergency \\
\hline LTE uplink scheduler & BQA [8] & Silence/talk spurt & Exponential \\
\hline Simulation time & $2000 \mathrm{~s}$ & length & $(3 \mathrm{~s})$ \\
\hline Time of disaster & $1000 \mathrm{~s}$ & Encoder scheme & GSM EFR \\
\hline
\end{tabular}

Table 1: Simulation Parameters

The simulation results of regular LTE traffic users are depicted in Figure 2. The green bars denote the end-to-end delay in the regular scenario $(t<1000 s)$, whereas the blue bars indicate the delay after an event of disaster $(t>1000 \mathrm{~s})$. The best effort traffic experiences the highest impact of the additional users in an emergency event. As illustrated in Figure 2a, these additional users drastically degrade the performance of the file transfer. This is mainly caused by the limited amount of remaining resources within the cell and by the low priority given by the LTE scheduler. This results in an average increase of the upload response time by the factor of 19.6. The simulation results of the M2M users are represented in Figure 2b as a subset of 10 users. These 10 users are randomly chosen and reflect the overall performance of all 100 M2M users. It can be seen, that all user experience a 4.8 fold increase of the upload response time. The voice user results (cf. Figure 2c) do not reveal a considerable effect of the increasing traffic load within the LTE cell. Since voice traffic is delay sensitive traffic, the LTE scheduler gives strict priority to this traffic. Resulting from this, the packet endto-end delay is increased on average by the factor 1.1 .

Even though the performance of voice user remains unaffected by the additional users during an emergency event, file upload and M2M traffic experience a considerable delay. In comparison to M2M traffic, file upload traffic experience a $\sim 4$ times higher delay. However, time sensitive M2M application, like e-healthcare, could suffer from this increase. 


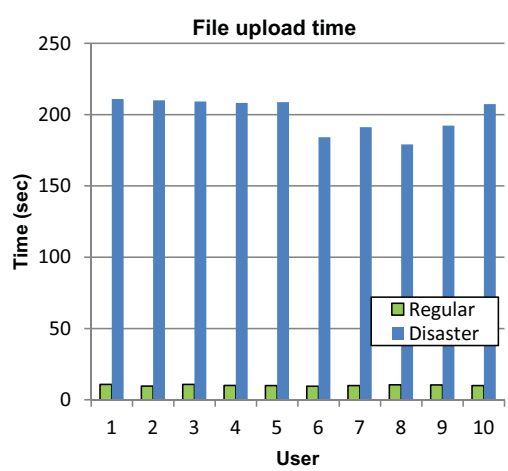

(a)

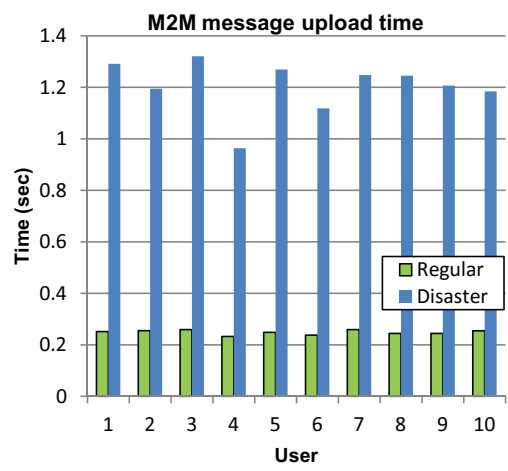

(b)

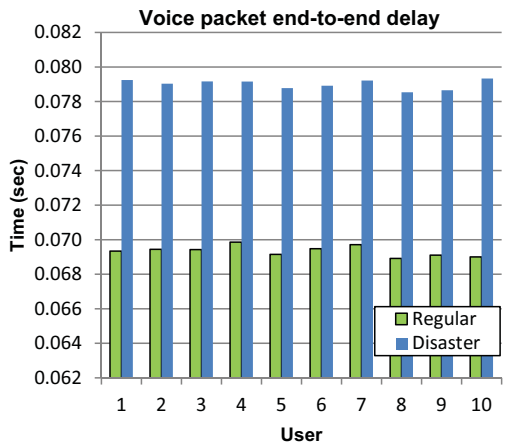

(c)

Fig. 2: (a) Average File Upload Time of File Transfer User (b) Average File Upload Time of M2M User (c) Average Voice User Packet End-to-End Delay

\section{References}

1. 3GPP Technical Report TR 25.913: Requirements for Evolved UTRA and UTRAN. v 2.1.0 (June 2005)

2. Cavallo, E., Noy, I.: The Economics of Natural Disasters: A Survey (2009)

3. Cisco Systems Inc.: Cisco Visual Networking Index: Global Mobile Data Traffic Forecast Update, 2012-2017. Digital Publication (Feb 2013)

4. Guha-Sapir, D., Hargitt, D., Hoyois, P.: Thirty Years of Natural Disasters 1974-2003: The Numbers. Presses univ. de Louvain (2004)

5. Hofmann, R.: Smart Operation of a Mobile Network in Event of Disaster. In: Proc. of 30th International Telecommunications Conference. SanDiego, USA (Sep 2008)

6. OPNET Modeler: http://www. opnet.com

7. Zaki, Y., Weerawardane, T., Görg, C., Timm-Giel, A.: Long Term Evolution (LTE) Model development within OPNET Simulation Environment. In: OPNET Workshop 2011. Washington D.C., USA (Aug 29 - Sep 1 2011)

8. Zaki, Y., Zahariev, N., Weerawardane, T., Görg, C., Timm-Giel, A.: Optimized Service Aware LTE MAC Scheduler: Design, Implementation and Performance Evaluation. In: OPNET Workshop 2011. Washington D.C., USA (Aug 29 - Sep 1 2011) 